\title{
Multi-stage Friend murine erythroleukemia: molecular insights into oncogenic cooperation Françoise Moreau-Gachelin ${ }^{1,2}$
}

Address: ${ }^{1}$ Inserm U830, 26 rue d'Ulm, 75248 Paris cedex 05, France and ${ }^{2}$ Institut Curie, 26 rue d'Ulm, 75248 Paris cedex 05, France

Email: Françoise Moreau-Gachelin - framoreau@curie.fr

Published: 4 November 2008

Retrovirology 2008, 5:99 doi:10.1186/1742-4690-5-99

This article is available from: http://www.retrovirology.com/content/5/I/99

(c) 2008 Moreau-Gachelin; licensee BioMed Central Ltd.

This is an Open Access article distributed under the terms of the Creative Commons Attribution License (http://creativecommons.org/licenses/by/2.0), which permits unrestricted use, distribution, and reproduction in any medium, provided the original work is properly cited.
Received: 2 October 2008

Accepted: 4 November 2008

\begin{abstract}
The Friend virus SFFV (Spleen Focus Forming Virus) provokes an acute erythroblastosis in susceptible strains of mice that progresses to overt erythroleukemia by a multi-step process. For virologists, the Friend virus-induced disease has provided deep insights into the host mechanisms influencing susceptibility to retroviral infection and viremia. These insights have contributed to the understanding of HIV and other human retroviral infections. For cell biologists and oncologists, this leukemia has been a powerful experimental model to identify critical oncogenes involved in a multistage process, to understand the contribution of host genes to cancer development, and to investigate the mechanisms leading to cell growth autonomy. This model also provided an example of oncogenic reversion since Friend tumor cells can reinitiate their erythroid differentiation program when exposed in vitro to some chemical inducers. This review highlights recent findings demonstrating that the leukemic progression depends on the cooperation of at least two oncogenic events, one interfering with differentiation and one conferring a proliferative advantage. The Friend model of leukemia progression recapitulates the two phases of human acute myeloid leukemia (AML). Coupling of insights from studies on the Friend erythroleukemia with knowledge on AML might allow a better understanding of the molecular mechanisms involved in the evolution of leukemia in mice and men.
\end{abstract}

\section{Review}

Friend retroviruses and Friend disease have provided powerful experimental tools in the fields of virology and oncology. During the nineteen-seventies, they have been of great importance in understanding the mechanisms of resistance of mice to retroviral infection, leading to the identification of several host genes that affect Friend virus replication in target cells and control host immune response to the viral antigens $[1,2]$. Recent advances made in primates retroviral restriction activities have given major relevance to the previously accrued murine data[3,4]. For example, the retroviral restriction factor Fv1 (Friend virus susceptibility factor 1 ) [5-8] provides resist- ance to infection by particular murine leukemia viruses, and the Ref1/Lv1/TRIM5 factor mediates resistance to diverse retroviruses in primates, including humans [9-11]. These mechanisms of resistance target a common capsid molecular determinant $[12,13]$. Remarkably, the murine gene Rfv3 (Recovery from Friend virus 3 ) which influences Friend viremia [14] and retroviral neutralizing antibody responses [15] encodes APOBEC3 known otherwise as a powerful antiretroviral factor that restricts retroviral virions of cognate origin [16-19]. Moreover, the erythroleukemia induced in mice by Friend retroviruses represent experimental neoplasms that have been valuable for characterizing the multi-stage progression of leukemia, for 
identifying oncogenes or tumor suppressor genes involved during this process, for understanding the contribution of host genes to cancer, and for investigating the mechanisms leading to cell growth autonomy. The purpose of this review is to highlight the important insights that have arisen from the studies on the Friend disease and to discuss the molecular events involved in the outgrowth of preleukemic cells and their progression to malignancy.

\section{Friend diseases}

Friend acute erythroleukemias are caused in susceptible mice by various strains of Friend leukemia viruses (FLV). The description of the initial isolate took place 50 years ago when the American virologist Charlotte Friend observed that newborn mice inoculated with Ehrlich murine carcinoma cells developed an acute erythroblastosis that could be subsequently transmitted by cell-free extracts prepared from the spleens of diseased mice [20]. The early description of the disease indicated that the original isolate (termed anemia-inducing Friend virus or FLVA) caused an anemia mainly due to hemodilution [21]. Since the original report by C. Friend, a number of other isolates capable of inducing a disease spectrum comparable to FLV-A have been identified. Among these, the Rauscher isolate was biologically similar to FLV-A [22]. A few years later, derivatives were obtained. In contrast to FLV-A causing an anemia, the derivatives increased the levels of erythrocytes in the peripheral blood (polycythemia) and was termed polycythemia-inducing Friend virus or FLV-P [23]. Adult or newborn mice inoculated with either FLV-A or FLV-P develop a disease with no latency. Both virus isolates induce an erythroblastosis that rapidly progresses to acute transformation (Figure 1). The early stage is characterized by a rapid increase in the number of proerythroblastic cells leading to massive hepatosplenomegaly that may be fatal by accidental spleen rupture. These proerythroblasts die in situ or differentiate into abnormal erythrocytes either in the absence of erythropoietin (Epo), in the case of FLV-P, or with a hypersensitivity to Epo, in the case of FLV-A[24-27]. The target cell in which both FLV-P and FLV-A express their pathogenic effect is an Epo-responsive progenitor cell that was identified as a late BFU-E or a CFU-E $[25,27,28]$. Although Friend virus-infected erythroid progenitors dramatically increase in number, they retain limited proliferation capacity and are not tumorigenic in vivo. Within two to three weeks after virus inoculation, a clonal population of proerythroblastic cells blocked in their differentiation program first emerges in the spleen and then invades the animal [29-31]. These leukemic cells have extensive proliferative capacity, the ability to be serially transplantable in vivo, and the capacity to eventually establish permanent cell lines in vitro. Cell lines established in culture were called Friend tumor cells. Of note, the erythroid differen- tiation program can be reinitiated in Friend tumor cells when exposed in vitro to some chemical inducers like dimethyl sulfoxyde, hexamethylene bisacetamide, butyric acid or hemin [32]. This contrasts importantly with Blymphocyte or T-lymphocyte transformation by Bovine Leukemia Virus (BLV) or Human T-cell Leukemia Virus (HTLV)[33] which are phenotypically irreversible. Thus, the Friend tumor cells have provided a useful in vitro model for studying the molecular processes of erythroid terminal differentiation.

\section{Friend viruses}

Both FLV-A and FLV-P isolates contain at least two viral components: a replication-competent Friend murine leukemia virus (F-MuLV) and a replication-defective spleen focus forming virus (SFFV). F-MuLV behaves as a helper supplying the replication-defective functions to SFFV, while SFFV is the pathogenic component responsible for the acute erythroblastosis. SFFV is responsible for the state of either polycythemia $\left(\mathrm{SFFV}_{\mathrm{P}}\right)$ or anemia $\left(\mathrm{SFFV}_{\mathrm{A}}\right)$. Further studies have demonstrated that the Rauscher SFFV (Ra-SFFV) was genetically equivalent to the Friend $\mathrm{SFFV}_{\mathrm{A}}[34,35]$. The conclusive proof that $\mathrm{SFFV}$ was the pathogenic component responsible for the acute erythroblastosis was that F-MuLV-free viral preparations containing only the SFFV genome could provoke an erythroid proliferative disease when inoculated in mice [36].

\section{The role of gp55 in erythroblastosis}

The SFFV genome differs from the genome of other acutely oncogenic retroviruses in that it does not contain oncogenic sequences derived from a cellular proto-oncogene. This property is similar to that observed for HTLV$1[37,38]$. The pathogenicity of SFFV stems from the product of its env gene that encodes a glycoprotein with a molecular mass of $55 \mathrm{kDa}\left(\mathrm{gp} 55_{\mathrm{P}}\right.$ and gp55 $\left.\mathrm{A}\right)[39,40]$. The env gene contains ecotropic env sequences derived from FMuLV and dual-tropic sequences probably acquired by genetic recombination with $e n v$ sequences from an endogenous polytropic virus present as multiple copies in the mouse genome [41]. Thus, gp55 presents structural elements homologous to polytropic env glycoproteins in its amino-terminal region and elements homologous to the ecotropic MuLV env gp70 in its carboxy-terminal part. The gp55 contains an extracellular domain, a transmembrane domain and a short cytoplasmic tail [42]. Gp55 is not processed in the viral particle but remains in the membranes of the infected cells. A small fraction of gp55 $(3-5 \%)$ is highly glycosylated in a gp65 form found anchored at the cell surface, while the majority of gp55 remains in the rough endoplasmic reticulum [34]. This glycosylation processing is required for the SFFV leukemogenic activity [43]. 
Step 1

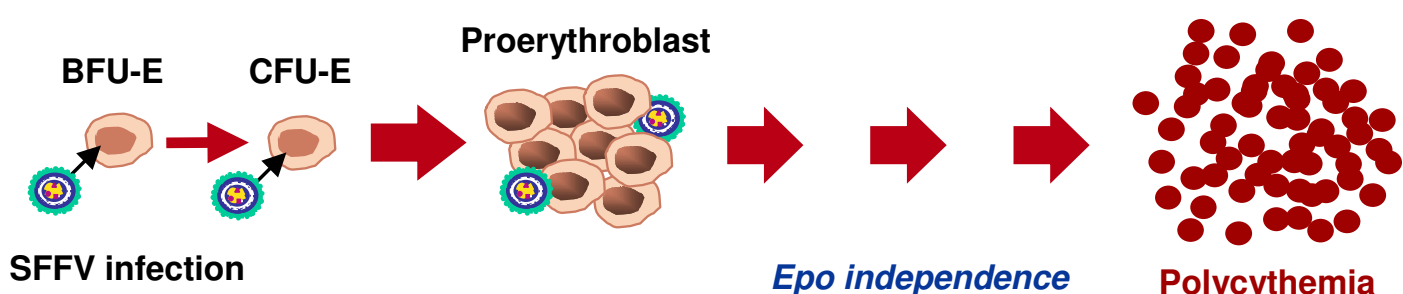

SFFV infection

Epo independence

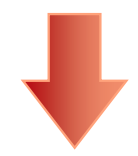

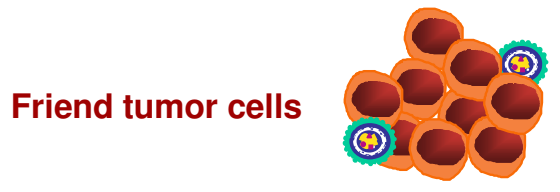

Differentiation arrest

Tumorigenicity
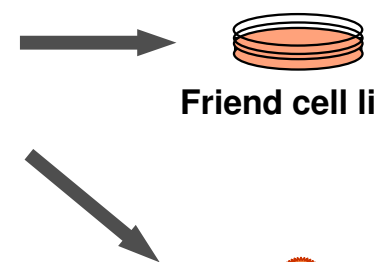

Friend cell line

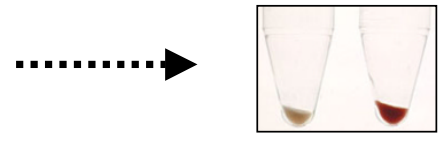

chemicals differentiation
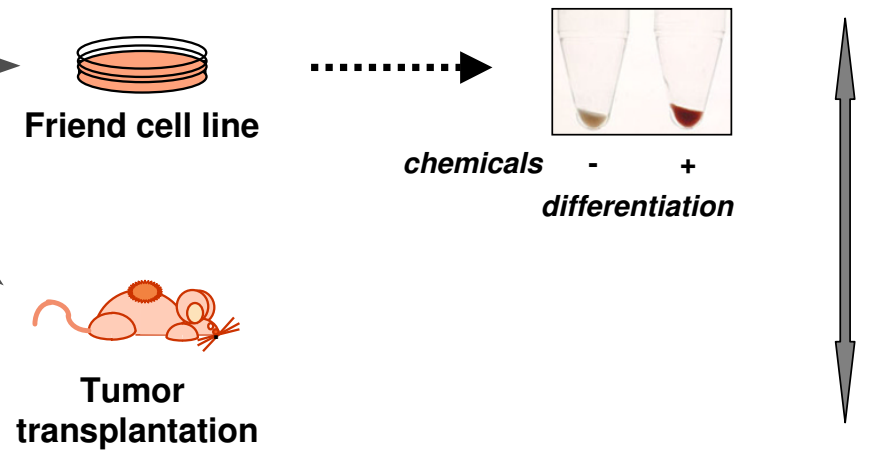

\section{Figure I}

Friend erythroleukemia is a two-step disease. The target cell for SFFV is a late BFU-E or a CFU-E. SFFV infection induces the proliferation of proerythroblastic cells that differentiate into erythrocytes in the absence of Epo, in the case of FLV-P infection. The second step is characterized by the outgrowth of Friend tumor cells that can be serially transplanted into mice and cultured as permanent cell lines without growth factor. The tumor cells are blocked in differentiation, but can be induced to differentiate along the erythroid pathway by chemical inducers. A pellet of red blood cells derived from a Friend tumor cell line treated for 5 days with DMSO is shown in the box.

To decipher the exact role of gp55 in the Friend disease, various models have been elaborated. A retroviral vector transducing only the gene encoding gp $55_{\mathrm{p}}$ was constructed. Upon inoculation in mice, it induced the early stage of the Friend disease similarly to that achieved with the entire $\mathrm{SFFV}_{\mathrm{P}}$ genome [44]. Another study used transgenesis. The gp $55_{\mathrm{P}}$-transgenic mice developed a polycythemia associated with a massive proliferation of erythroid precursor cells that were not transplantable [45]. Thus, these elegant approaches provided convincing evidence that gp55 is directly responsible for the early erythroblastosis.

An important insight into the gp55 function in erythroid precursor cells was the demonstration that gp55 directly interacts with the receptor for erythropoietin (EpoR) [46]. This interaction occurs through the respective transmem- brane domains of EpoR and gp55. The binding of gp55 to EpoR, that is highly expressed at the transition of late BFU-E to CFU-E, results in EpoR activation and promotes the Epo-independent proliferation and differentiation of erythroid progenitor cells $[42,43,47,48]$. Rare amino acid differences have been identified in the transmembrane domains of gp $55_{\mathrm{P}}$ and $\mathrm{gp} 55_{\mathrm{A}}$. Due to these differences, the level of EpoR activation remains incomplete with gp $55_{\mathrm{A}}$ explaining the increase in Epo sensitivity [49] but not autonomy from Epo. In addition to EpoR, gp55 also recruits the short form of the stem-cell-kinase receptor (sfStk) as a signaling partner $[50,51]$. Stk/RON is a tyrosine kinase receptor of the Met family. sf-Stk retains the transmembrane and the tyrosine kinase domains, but lacks the extracellular ligand binding domain of Stk [51-53]. Stk/ RON is encoded by the Fv2 gene (Friend virus susceptibility gene 2) [52], previously known as a gene determining 
the susceptibility of some strains of mice $\left(\mathrm{Fv} 2^{\mathrm{s} / \mathrm{s}}\right)$ to the Friend disease $[54,55]$. Transcription of $s f$-Stk is naturally initiated from an internal promoter within the Stk gene, and this internal promoter is deleted in mice resistant to Friend virus $\left(\mathrm{Fv} 2^{\mathrm{r} / \mathrm{r}}\right)$ [52]. Strikingly, the pathology that developed in gp $55_{\mathrm{p}}$-transgenic mice was not observed under the genetic $F v 2^{r / r}$ background [45], emphasizing the essential role of sf-Stk in gp55-mediated erythroid proliferation. In SFFV-infected mice, gp55, EpoR and sf-Stk are effectors in signaling pathways which encompass the signal transducers and transcriptional activators STATs $[56,57]$, PI3-kinase/AKT [50], the molecular adaptors Grb2/Gab2 [58], the Lyn kinase [59], the p38MAP kinase [60], and the ERK1/2 MAP kinases [61,62]. Constitutive activation of these signaling pathways by the gp55/EpoR and gp55/sf-Stk complexes leads to the dysregulation of proliferation, survival and differentiation of $\mathrm{SFFV}_{\mathrm{P}^{-}}$ infected erythroid progenitors in $\mathrm{Fv}^{\mathrm{s} / \mathrm{s}}$ mice which result in acute erythroblastosis.

\section{The oncogenic events during Friend erythroleukemia}

Although SFFV is an acutely transforming retrovirus, it induces malignant transformation of erythroid cells by a mechanism of insertional mutagenesis which is usually employed by non-acute leukemogenic virus. Identification of SFFV proviruses integration sites in the genome of various Friend tumor cells was the first molecular proof for the clonal nature of the leukemic transformation [63]. The molecular characterization of the SFFV integration sites revealed that $\mathrm{SFFV}_{\mathrm{P}}$ or $\mathrm{SFFV}_{\mathrm{A}}$ preferentially integrates at the same genomic locus in $95 \%$ of the Friend tumor cells, called spi-1 for SFFV proviral integration site-1 $[64,65]$. The spi-1 locus is transcriptionally activated by the transcriptional enhancers present in the SFFV LTR $[66,67]$, producing the overexpression of a normal spi-1 mRNA translated into a normal Spi-1 protein $[66,68]$. During DMSO-induced erythroid differentiation of Friend tumor cells, it was noticed that one of the early events was a marked decline in the level of Spi-1 expression [69]. Based on this observation, it was proposed that the arrest in erythroid differentiation was, at least in part, due to Spi-1 overexpression. The high recurrence of Spi-1 insertional mutation in Friend tumor cells suggested that Spi-1 overexpression was cooperative with the constitutive signaling from gp55/EpoR and sf-Stk/EpoR complexes to induce the malignant transformation of the proerythroblast. Indeed, in a heterologous avian model of erythroid self-renewal and differentiation, the effects of Spi-1 on proliferation, survival and differentiation arrest required the co-expression of Spi-1 with an EpoR activated either by gp 55 or by a mutation on the residue R129C, which mimics EpoR/gp55 activation [70-72].

Besides Spi-1 overexpression, recurrent alterations in the tumor suppressor $p 53$ gene were also detected in the late stage of the Friend disease. Allelic deletions or missense mutations led to loss of p53 tumor suppressive function [73-75], and it was shown that Friend leukemia develop more rapidly in transgenic mice expressing a mutant p53 allele, or in p53-null mice, than in normal mice $[76,77]$. Although the ectopic expression of a normal p53 protein in Friend tumor cells induces apoptosis and hemoglobin production [78], the loss or the mutation of p53 seems to favor the growth and survival of leukemic proerythroblasts rather than specifically altering erythroid differentiation.

\section{The role of Spi-I in the arrest of erythroid differentiation}

To specify the role of Spi-1 in erythroleukemia, a murine model of spi-1 transgenesis has been constructed [79]. The $s p i-1$ transgene, placed under the control of the $S_{F F V}$ LTR, $_{\text {, }}$ was introduced into the germinal lineage of $\mathrm{Fv}^{s / s}$ mice. Spi-1 transgenic mice develop, within 3 to 4 months after birth, a severe anemia and a massive swelling of the spleen followed by an enlargement of the liver. Bone marrow, spleen, and liver are infiltrated by proerythroblasts arrested in differentiation, mostly at the basophilic stage. These proerythroblastic cells can be established in vitro as permanent cell lines that are exquisitely dependent on Epo for proliferation and survival, and the cells are unable to induce tumors when engrafted in vivo. The Epo dependency was confirmed in vivo by the demonstration that elevation of hematocrit levels (above 60\%) by repeated red blood cells transfusions caused regression of the hepatosplenomegaly and disappearance of circulating blasts. Nonetheless, in the animal, erythroblasts expansion occurs in both the presence of Epo in the plasma and the secretion of SCF (stem cell factor) in the marrow or spleen microenvironment. In fact, SCF cooperates with Epo to maintain the in vitro survival and proliferation of the spi-1 transgenic proerythroblasts when Epo is used at limiting concentrations [80]. Thus, the spi-1 transgenic model demonstrates that an ectopic expression of Spi-1 results in a block in the maturation program of erythroid precursor cells without removing their growth factor requirement for survival.

The function of Spi-1 in the erythroid differentiation blockage is multifaceted. The extinction of Spi-1 by spi-1interfering RNAs in spi-1 transgenic proerythroblasts is sufficient to reinstate the erythroid differentiation program [81]. This differentiation process is associated with an arrest in proliferation due to both cell death by apoptosis and cell cycle arrest. The mechanisms controlled by Spi-1 that permit survival of the proerythroblast and avoid an exit from the cell cycle are still subjected to speculation. Spi-1 is identical to the transcription factor PU.1, a member of the ETS family. Studies with PU.1 knock-out mice have shown that PU.1 supports hematopoiesis at different stages. Deficiency in PU.1 results in the selective loss of B 
lymphoid and macrophage development, and a delayed development of neutrophils and T cells [82-86]. In addition, PU. 1 plays a role in regulating the commitment of multipotent hematopoietic progenitors $[87,88]$. Spi-1/ PU.1 functions require the ability of the protein to bind purine-rich DNA sequences in the promoters and enhancers of target genes $[68,89]$. Distinct threshold levels of PU.1 also determine function, with high levels driving precursors to a myeloid cell fate, while moderate levels specify B lymphoid development [90]. Notably, Spi-1/ PU.1 down-regulation is required for normal erythroid development $[91,92]$. Thus, Spi-1 overexpression in the proerythroblast probably changes the delicate balance of transcriptional activities required for normal erythropoiesis.

It was postulated that excess Spi-1 may disrupt the function of an erythroid factor and, in this hypothesis, GATA1 was an obvious candidate [93-95]. Indeed, GATA-1-deficient erythroid cells fail to mature beyond the proerythroblast stage and die by apoptosis $[96,97]$. Several studies have reported a reciprocal inhibition of Spi-1/PU.1 and GATA-1 functions through direct interaction [98-101]. Furthermore, the concept that Spi-1 could inhibit the function of GATA-1 in erythroleukemic cells is supported by the reversal of tumorigenicity and the re-initiation of a differentiation program when GATA-1 expression is ectopically imposed in a Friend tumor cell line [102]. Nonetheless, target genes for GATA-1, such as EKLF, NFE2, $\beta$ globin, EpoR and GATA-1-itself are expressed in both Friend and spi-1 transgenic cells [79](our unpublished data) indicating that some GATA-1 functions are not abolished by Spi-1 overexpression. Global transcriptome analyses of preleukemic spi-1 transgenic proerythroblasts should provide data allowing the elucidation of the direct targets downstream Spi-1 and the molecular pathways leading to erythroleukemogenesis. As a first indication, transcription of the fli-1 gene is directly regulated by Spi-1 in Friend tumor cells [103]. Fli-1 is a transcription factor of the ETS family that behaves as an oncogene when activated by insertional mutagenesis in late erythroid tumors induced by the Friend MuLV alone [104]. Thus, Fli-1 dysregulation may contribute, in part, to the erythroid differentiation arrest induced by Spi- 1 . Another mechanism may involve the phosphatase SHP-1 [105] that is transcriptionally up regulated by Spi-1 [106]. SHP-1 may interfere with the activation of STAT1 and STAT3 and inhibit their DNA binding activities, contributing to the erythroid differentiation arrest[57].

\section{The two-stage erythroleukemia in spi-I transgenic mice} During disease progression, fully transformed proerythroblastic cells emerge that are characterized by both autonomous growth in vitro and tumorigenicity in vivo. Thus, like the disease induced by the Friend virus com- plex, spi-1 transgenic mice develop a malignant process that evolves in two steps (Figure 2) whereby the blastic phase reflects the outgrowth of a malignant erythroblastic cell subpopulation with acquired genetic lesions. According to the data accumulated with studies on the Friend disease, abnormalities occurring in the $p 53$ gene were examined. Inactivating p53 mutations were frequently observed in malignant spi-1 transgenic proerythroblasts, and we reported that disease progression was highly accelerated in a p53-null background [107]. Nevertheless, Epodependent and non-tumorigenic cells can be isolated during the early erythroblastic phase of diseased p53\%-spi-1 transgenic mice indicating that $p 53$ germline deletion is not sufficient to confer the malignant phenotype in this context [108]. As for the Friend disease, p53 abnormalities appear more as a permissive event supporting the illegitimate survival of proerythroblasts harboring genetic aberrations than a direct transformation event.

Next, signaling alterations were prospected. These studies led to the identification of point mutations in the Kit gene in $86 \%$ of tumors isolated late during leukemia progression [80]. Kit, the tyrosine kinase receptor for SCF, is expressed on hematopoietic stem cells and committed progenitor cells of the different blood cell lineages $[109,110]$. Kit is activated by SCF binding, which induces receptor dimerization followed by the activation of the intrinsic tyrosine kinase and receptor transphosphorylation on specific tyrosine residues $[111,112]$. By triggering multiple signaling pathways including ERK1/2 MAP kinases, PI3Kinase, and Src kinases, Kit activation modulates cell survival and proliferation [113-115]. Most Kit mutations found in spi-1 transgenic leukemic cells affect amino acids located in the Kit catalytic domain (mainly codon 814 and occasionally codon 818 ). Of note, similar mutations were found in human mastocytosis [116,117] and acute myeloid leukemia [118-120]. These gain-offunction mutations confer ligand-independent tyrosine kinase activity to Kit. The mutated forms of Kit constitutively activate MAP kinases and PI3Kinase/AKT pathways in the spi-1 transgenic leukemic cells [80,121]. When the expression of Kit mutants is enforced in spi-1 transgenic preleukemic proerythroblasts, cells become growth-factor independent and tumorigenic in vivo. Thus, a constitutive signaling from Kit mutants combined to Spi-1 overexpression leads to malignant transformation of proerythroblasts (Figure 3).

\section{From murine to human}

AML in human are characterized by an uncontrolled expansion of immature blasts, which fail to differentiate normally. These leukemias are classified into sub-types according to the predominance of the altered myeloid lineage. It is currently accepted that the disease progresses from a chronic phase to an acute blastic crisis. Molecu- 


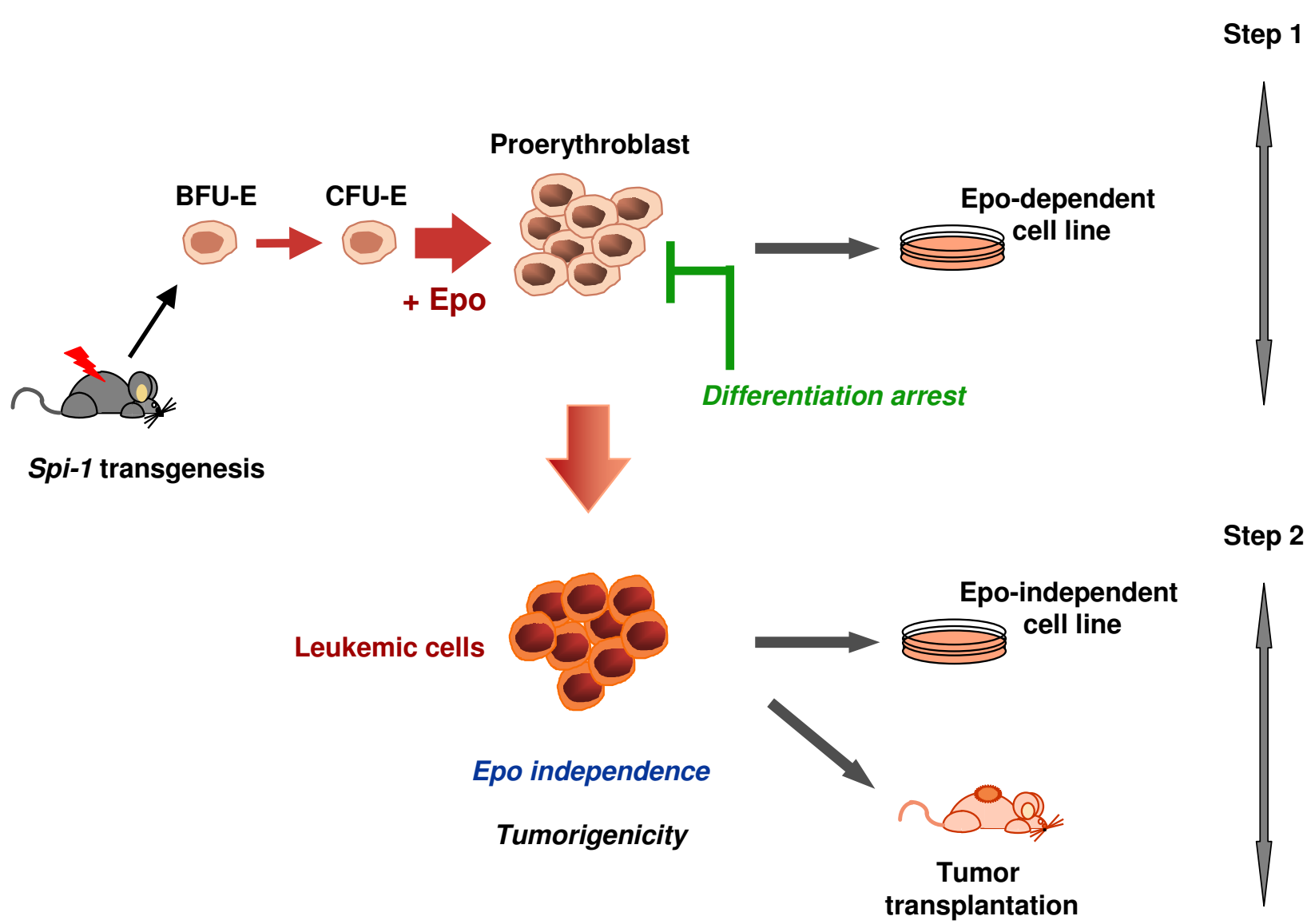

Figure 2

Erythroleukemia in spi-I transgenic mice is a two-step disease. The first step occurring in spi- $I$ transgenic mice is a massive proliferation of proerythroblasts, arrested in differentiation around the CFU-E/proerythroblast stage. These cells can be established in vitro as Epo-dependent cell lines. In a second step, malignant proerythroblastic cells emerge that proliferate in vitro without Epo and are tumorigenic when grafted into Nude mice.

larly, leukemias are associated with multiple genetic alterations, including chromosomal translocations and mutations. Overviews on the genetic alterations found in AML are detailed in recent reviews [122-127]. One important observation is that the genetic alterations can be divided into two classes. One class targets transcription factors that play a regulatory role in hematopoietic development. These transcription factors are frequently modified through chromosomal translocations and the resulting chimeric proteins inhibit differentiation in a particular hematopoietic cell lineage. For example, the promyelocytic leukemia-retinoic acid receptor $\alpha$ (PML/ RAR $\alpha$ ) expressed from the $\mathrm{t}(15 ; 17)$ translocation is associated with $99 \%$ of acute promyelocytic leukemia [128]. $\mathrm{PML} / \mathrm{RAR} \alpha$ behaves as a transcriptional repressor for the hormonal receptor RAR $\alpha$ [129]. In the second class, mutations affect signaling effectors like tyrosine kinases [125]. These mutations are gain-of-function and provide prolif- erative signals, as exemplified by point mutations inducing the constitutive activation of the tyrosine kinase receptor FLT3 in 30\% of AML $[122,130,131]$. Strikingly, murine models designed to express one genetically modified protein, using the transplantation of retrovirallytransduced bone marrow cell or transgenesis, showed that one type of mutation does not induce an acute leukemia on its own. Generally, they provoke a myeloproliferative disorder. Progression to leukemia requires either a long latency, making plausible the occurrence of a second mutation, or an additional treatment with mutagenic compounds. The concept emerging from this complexity is that an acute leukemia arises from the cooperation between two events: one mutation interfering with differentiation and the other mutation conferring a proliferation advantage [132]. 


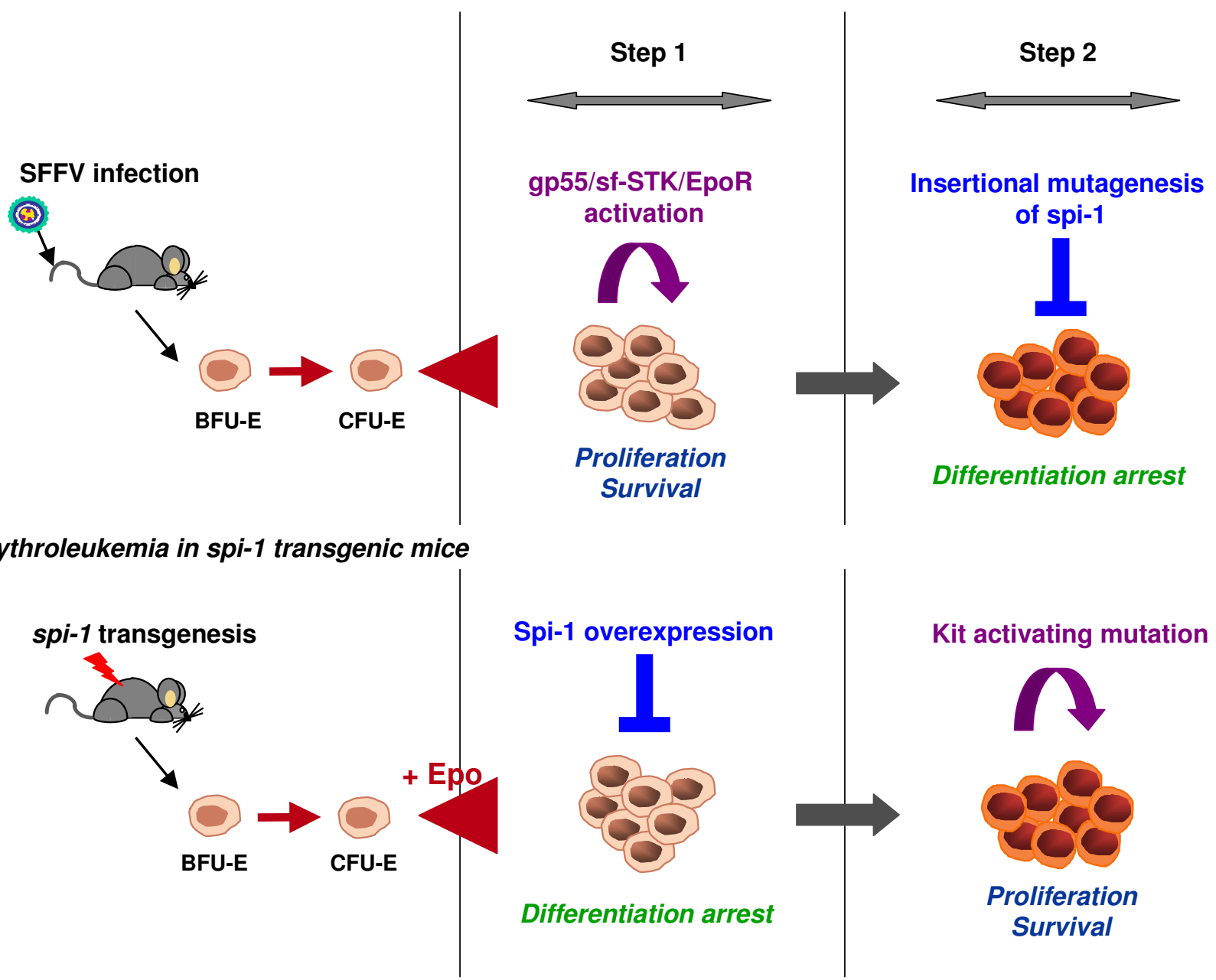

Figure 3

Oncogenic cooperation in murine erythroleukemia. During Friend acute erythroleukemia, the early expansion of erythroid progenitors is due to the activation of EpoR and sf-STK by the viral gp55. The blastic crisis is associated with the overexpression of the transcription factor Spi-I/PU.I, occurring by insertional mutagenesis due to SFFV. During erythroleukemia progression in spi-I transgenic mice, the initial oncogenic event is the overexpression of Spi- I/PU.I by germinal mutation that induces a differentiation arrest of the proerythroblast. The blastic crisis is associated with activating mutations in the Kit gene that promote the Epo-independent proliferation and survival of the malignant proerythroblast.

Both the Friend and spi-1 transgenic models demonstrate that leukemia development depends on the cooperation between one mutation that impairs differentiation and a second mutation that promotes autonomous cell growth (Figure 1). In that way, these murine models provide proof-of-principle for the "two-hits" model of leukemogenesis [132]. They highlight that complementation between the two classes of mutations is more important for leukemogenesis than the timing order of their occurrence.

\section{Conclusion}

Significant advances have been made in the mechanisms of leukemia from studies on murine models of erythroleukemia. In the nineteen-sixties, these studies established the concept of multiple-step evolution of leukemia. Forty years later, these models validate the concept of oncogenic cooperativity merging the diversity of genetic lesions that underlie the development of acute myeloid leukemia in human. A future challenge will be to integrate the networks of transcriptional regulation and signaling toward a better understanding of leukemogenic processes. 


\section{Competing interests}

The author(s) declare that they have no competing interests.

\section{Acknowledgements}

I am grateful to C Guillouf, D Buet, P Rimmele for insightful discussions. I sincerely thank $F$ Wendling for providing critical comments and suggestions on the manuscript.

\section{References}

I. Kabat D: Molecular biology of Friend viral erythroleukemia. Curr Top Microbiol Immunol 1989, I 48: I-42.

2. Chesebro B, Miyazawa M, Britt WJ: Host genetic control of spontaneous and induced immunity to Friend murine retrovirus infection. Annu Rev Immunol 1990, 8:477-499.

3. Goff SP: Retrovirus restriction factors. Mol Cell 2004, I 6:849-859.

4. Miyazawa M, Tsuji-Kawahara S, Kanari Y: Host genetic factors that control immune responses to retrovirus infections. Vaccine 2008, 26:298I-2996.

5. Lilly F: Susceptibility to two strains of Friend leukemia virus in mice. Science 1967, 155:461-462.

6. Pincus T, Rowe WP, Lilly F: A major genetic locus affecting resistance to infection with murine leukemia viruses. II. Apparent identity to a major locus described for resistance to friend murine leukemia virus. J Exp Med 197I, 133:|234-124I.

7. Jolicoeur P: The Fv-I gene of the mouse and its control of murine leukemia virus replication. Curr Top Microbiol Immunol 1979, 86:67-122.

8. Best S, Le Tissier P, Towers G, Stoye JP: Positional cloning of the mouse retrovirus restriction gene FvI. Nature 1996, 382:826-829.

9. Towers G, Bock M, Martin S, Takeuchi Y, Stoye JP, Danos O: A conserved mechanism of retrovirus restriction in mammals. Proc Natl Acad Sci USA 2000, 97: I 2295-I 2299.

10. Stremlau M, Owens CM, Perron MJ, Kiessling M, Autissier P, Sodroski $\mathrm{J}$ : The cytoplasmic body component TRIM5alpha restricts HIV-I infection in Old World monkeys. Nature 2004, 427:848-853.

II. Hatziioannou T, Perez-Caballero D, Yang A, Cowan S, Bieniasz PD: Retrovirus resistance factors Ref I and LvI are species-specific variants of TRIM5alpha. Proc Natl Acad Sci USA 2004, I 0 I: 10774-10779.

12. Stevens A, Bock M, Ellis S, LeTissier P, Bishop KN, Yap MW, Taylor W, Stoye JP: Retroviral capsid determinants of FvI NB and NR tropism. J Virol 2004, 78:9592-9598.

13. Lassaux A, Sitbon M, Battini JL: Residues in the murine leukemia virus capsid that differentially govern resistance to mouse FvI and human Refl restrictions. J Virol 2005, 79:6560-6564.

14. Chesebro B, Wehrly K: Identification of a non-H-2 gene (Rfv-3) influencing recovery from viremia and leukemia induced by Friend virus complex. Proc Natl Acad Sci USA 1979, 76:425-429.

15. Doig $D$, Chesebro $B$ : Anti-Friend virus antibody is associated with recovery from viremia and loss of viral leukemia cellsurface antigens in leukemic mice. Identification of Rfv-3 as a gene locus influencing antibody production. J Exp Med 1979, I50:10-19.

16. Stopak K, de Noronha C, Yonemoto W, Greene WC: HIV-I Vif blocks the antiviral activity of APOBEC3G by impairing both its translation and intracellular stability. Mol Cell 2003, I 2:59|-601.

17. Marin M, Rose KM, Kozak SL, Kabat D: HIV-I Vif protein binds the editing enzyme APOBEC $3 G$ and induces its degradation. Nat Med 2003, 9:1398-I403.

18. Santiago ML, Montano M, Benitez R, Messer RJ, Yonemoto W, Chesebro B, Hasenkrug KJ, Greene WC: Apobec3 encodes Rfv3, a gene influencing neutralizing antibody control of retrovirus infection. Science 2008, 32 I: | 343-I346.

19. Takeda E, Tsuji-Kawahara S, Sakamoto M, Langlois MA, Neuberger MS, Rada C, Miyazawa M: Mouse APOBEC3 restricts Friend leukemia virus infection and pathogenesis in vivo. J Virol 2008 , 82(22): I0998-I 1008.
20. Friend C: Cell-free transmission in adult Swiss mice of a disease having the character of a leukemia. J Exp Med 1957, 105:307-318.

21. Tambourin PE, Wendling F, Jasmin C, Smadja-Joffe F: The physiopathology of Friend leukemia. Leuk Res 1979, 3:I I7-I 29.

22. Rauscher FJ: A virus-induced disease of mice characterized by erythrocytopoiesis and Iymphoid leukemia. J Natl Cancer Inst 1962, 29:515-543.

23. Mirand EA: Virus-induced erythropoiesis in hypertransfusedpolycythemic mice. Science 1967, I 56:832-833.

24. Mirand EA, Steeves RA, Lange RD, Grace JT Jr: Virus-induced polycythemia in mice: erythropoiesis without erythropoietin. Proc Soc Exp Biol Med 1968, I 28:844-849.

25. Tambourin P, Wendling F: Malignant transformation and erythroid differentiation by polycythaemia-inducing Friend virus. Nat New Biol 197I, 234:230-233.

26. Liao SK, Axelrad AA: Erythropoietin-independent erythroid colony formation in vitro by hemopoietic cells of mice infected with friend virus. Int J Cancer 1975, I 5:467-482.

27. Tambourin PE, Wendling F: Target cell for oncogenic action of polycythaemia-inducing Friend virus. Nature 1975, 256:320-322.

28. Fredrickson T, Tambourin P, Wendling F, Jasmin C, Smajda F: Target cell of the polycythemia-inducing Friend virus: studies with myleran. J Natl Cancer Inst 1975, 55:443-446.

29. Tambourin P, Wendling F, Moreau-Gachelin F: Friend leukemia as a multiple-step disease. Blood Cells |98|, 7:|33-|44.

30. Mager DL, Mak TW, Bernstein A: Quantitative colony method for tumorigenic cells transformed by two distincts strains of Friend leukemia virus. Proc Nat Acad Sci USA 1981, 78: I 703-I 707.

31. Ben-David $Y$, Bernstein A: Friend virus-induced erythroleukemia and the multistage nature of cancer. Cell 1991, 66:83I-834.

32. Marks PA, Rifkind RA: Erythroleukemic differentiation. Annu Rev Biochem 1978, 47:419-448.

33. Gillet N, Florins A, Boxus M, Burteau C, Nigro A, Vandermeers F, Balon $H$, Bouzar AB, Defoiche J, Burny A, Reichert M, Kettmann R, Willems $L$ : Mechanisms of leukemogenesis induced by bovine leukemia virus: prospects for novel anti-retroviral therapies in human. Retrovirology 2007, 4: 18.

34. Ruta M, Kabat D: Plasma membrane glycoproteins encoded by cloned Rauscher and Friend spleen focus-forming viruses. J Virol 1980, 35:844-853.

35. Vogt M, Haggblom C, Swift S, Haas M: Envelope gene and long terminal repeat determine the different biological properties of Rauscher, Friend, and Moloney mink cell focus-inducing viruses. J Virol 1985, 55:184-192.

36. Wolff $L$, Ruscetti $S$ : Malignant transformation of erythroid cells in vivo by introduction of a nonreplicating retrovirus vector. Science 1985, 228: 1549-1552.

37. Matsuoka M, Jeang KT: Human T-cell leukaemia virus type I (HTLV-I) infectivity and cellular transformation. Nat Rev Cancer 2007, 7:270-280.

38. Matsuoka M: Human T-cell leukemia virus type I (HTLV-I) infection and the onset of adult T-cell leukemia (ATL). Retrovirology 2005, 2:27.

39. Linemeyer DL, Menke JG, Ruscetti SK, Evans LH, Scolnick EM: Envelope gene sequences which encode the gp52 protein of spleen focus-forming virus are required for the induction of erythroid cell proliferation. J Virol 1982, 43:223-233.

40. Ruta M, Bestwick R, Machida C, Kabat D: Loss of leukemogenicity caused by mutations in the membrane glycoprotein structural gene of Friend spleen focus-forming virus. Proc Natl Acad Sci USA 1983, 80:4704-4708.

41. Clark SP, Mak TW: Fluidity of a retrovirus genome. Journal of Virology 1984, 50:759-765.

42. Zon LI, Moreau JF, Koo JW, Mathey-Prevot B, D'Andrea AD: The erythropoietin receptor transmembrane region is necessary for activation by the Friend spleen focus-forming virus gp55 glycoprotein. Mol Cell Biol 1992, I 2:2949-2957.

43. Li JP, Hu HO, Niu QT, Fang C: Cell surface activation of the erythropoietin receptor by friend spleen focus-forming virus gp55. J Virol 1995, 69:1714-1719.

44. Wolff $L$, Ruscetti S: The spleen focus-forming virus (SFFV) envelope gene, when introduced into mice in the absence of 
other SFFV genes, induces acute erythroleukemia. J Virol 1988, 62:2158-2163.

45. Aizawa S, Suda Y, Furuta Y, Yagi T, Takeda N, Watanabe N, Nagayoshi M, lkawa Y: Env-derived gp55 gene of Friend spleen focusforming virus specifically induces neoplastic proliferation of erythroid progenitor cells. EMBO J 1990, 9(7):2107-2II6.

46. Li JP, D'Andrea AD, Lodish HF, Baltimore D: Activation of cell growth by binding of Friend spleen focus-forming virus gp 55 glycoprotein to the erythropoietin receptor. Nature 1990, 343:762-764.

47. Chung SW, Wolff $L$, Ruscetti SK: Transmembrane domain of the envelope gene of a polycythemia-inducing retrovirus determines erythropoietin-independent growth. Proc Natl Acad Sci USA 1989, 86:7957-7960.

48. Ruscetti SK, Janesch NJ, Chakraborti A, Sawyer ST, Hankins WD: Friend Spleen-Focus-forming virus induces factor independence in an erythropoietin-dependent erythroleukemia cell line. J Virol 1990, 64:1057-1062.

49. Constantinescu SN, Keren T, Russ WP, Ubarretxena-Belandia I, Malka Y, Kubatzky KF, Engelman DM, Lodish HF, Henis YI: The erythropoietin receptor transmembrane domain mediates complex formation with viral anemic and polycythemic gp55 proteins. I Biol Chem 2003, 278:43755-43763.

50. Nishigaki K, Thompson D, Hanson C, Yugawa T, Ruscetti S: The envelope glycoprotein of friend spleen focus-forming virus covalently interacts with and constitutively activates a truncated form of the receptor tyrosine kinase Stk. J Virol 200I, 75:7893-7903

5I. Zhang J, Randall MS, Loyd MR, Li W, Schweers RL, Persons DA, Rehg JE, Noguchi CT, Ihle JN, Ney PA: Role of erythropoietin receptor signaling in Friend virus-induced erythroblastosis and polycythemia. Blood 2006, 107:73-78.

52. Persons DA, Paulson RF, Loyd MR, Herley MT, Bodner SM, Bernstein A, Correll PH, Ney PA: Fv2 encodes a truncated form of the Stk receptor tyrosine kinase. Nat Genet 1999, 23:159-165.

53. Rulli K, Yugawa T, Hanson C, Thompson D, Ruscetti S, Nishigaki K: Ex vivo and in vivo biological effects of a truncated form of the receptor tyrosine kinase stk when activated by interaction with the friend spleen focus-forming virus envelope glycoprotein or by point mutation. J Virol 2004, 78:4573-458I.

54. Lilly F: Fv-2: identification and location of a second gene governing the spleen focus response to Friend leukemia virus in mice. I Natl Cancer Inst 1970, 45: I63-169.

55. Iwama A, Okano K, Sudo T, Matsuda Y, Suda T: Molecular cloning of a novel receptor tyrosine kinase gene, STK, derived from enriched hematopoietic stem cells. Blood 1994, 83:3।60-3169.

56. Yamamura $Y$, Senda H, Kageyama $Y$, Matsuzaki T, Noda M, Ikawa $Y$ : Erythropoietin and friend virus gp55 activate different JAK/ STAT pathways through the erythropoietin receptor in erythroid cells. Mol Cell Biol 1998, I8: I 172-I। 80.

57. Nishigaki K, Hanson C, Ohashi T, Spadaccini A, Ruscetti S: Erythroblast transformation by the friend spleen focus-forming virus is associated with a block in erythropoietin-induced STATI phosphorylation and DNA binding and correlates with high expression of the hematopoietic phosphatase SHP-I. J Virol 2006, 80:5678-5685.

58. Teal HE, Ni S, Xu J, Finkelstein LD, Cheng AM, Paulson RF, Feng GS, Correll PH: GRB2-mediated recruitment of GAB2, but not GABI, to SF-STK supports the expansion of Friend virusinfected erythroid progenitor cells. Oncogene 2006, 25:2433-2443.

59. Subramanian A, Hegde S, Correll PH, Paulson RF: Mutation of the Lyn tyrosine kinase delays the progression of Friend virus induced erythroleukemia without affecting susceptibility. Leuk Res 2006, 30: I| 41-11449.

60. Jelacic TM, Thompson D, Hanson C, Cmarik JL, Nishigaki K, Ruscetti $\mathrm{S}$ : The tyrosine kinase sf-Stk and its downstream signals are required for maintenance of friend spleen focus-forming virus-induced fibroblast transformation. J Virol 2008, 82:419-427.

61. Muszynski KW, Ohashi T, Hanson C, Ruscetti SK: Both the polycythemia- and anemia-inducing strains of Friend spleen focus-forming virus induce constitutive activation of the RafI/mitogen-activated protein kinase signal transduction pathway. J Virol 1998, 72:919-925.
62. Muszynski KW, Thompson D, Hanson C, Lyons R, Spadaccini A, Ruscetti SK: Growth factor-independent proliferation of erythroid cells infected with friend spleen focus-forming virus is protein kinase $\mathbf{C}$ dependent but does not require rasGTP [In Process Citation]. J Virol 2000, 74:8444-845I.

63. Moreau-Gachelin F, Robert-Lezenes J, Wendling F, Tavitian A, Tambourin P: Integration of spleen focus-forming virus proviruses in Friend tumor cells. J Virol 1985, 53:292-295.

64. Moreau-Gachelin F, Tavitian A, Tambourin P: Spi-I is a putative oncogene in virally induced murine erythroleukemia. Nature (London) 1988, 331:277-280.

65. Paul R, Schuetze S, Kozak SL, Kabat D: A common site for immortalizing proviral integrations in Friend erythroleukemia: molecular cloning and characterization. J Virol 1989, 63:4958-496I.

66. Moreau-Gachelin F, Ray D, Mattei MG, Tambourin P, Tavitian A: The putative oncogene Spi-I: murine chromosomal localization and transcriptional activation in murine acute erythroleukemias [published erratum appears in Oncogene 1990 Jun;5(6):94I]. Oncogene 1989, 4:|449-|456.

67. Okuno Y, Huang G, Rosenbauer F, Evans EK, Radomska HS, Iwasaki $\mathrm{H}$, Akashi K, Moreau-Gachelin F, Li Y, Zhang P, Göttgens B, Tenen DG: Potential autoregulation of transcription factor PU.I by an upstream regulatory element. Mol Cell Biol 2005, 25:2832-2845.

68. Paul R, Schuetze S, Kozak SL, Kozak CA, Kabat D: The Sfpi-I proviral integration site of Friend erythroleukemia encodes the ets-related transcription factor Pu. I. J Virol I99I, 65:464-467.

69. Schuetze S, Paul R, Gliniak BC, Kabat D: Role of the PU.I transcription factor in controlling differentiation of Friend erythroleukemia cells. Mol Cell Biol 1992, I 2:2967-2975.

70. Longmore GD, Lodish HF: An activating mutation in the murine erythropoietin receptor induces erythroleukemia in mice: a cytokine receptor superfamily oncogene. Cell |99|, 67:1089-1102.

7I. Tran Quang C, Wessely O, Pironin M, Beug H, Ghysdael J: Cooperation of Spi-I/PU.I with an activated erythropoietin receptor inhibits apoptosis and Epo-depedent differenciation in primary erythroblasts and induces their kit ligand-dependent proliferation. EMBO 」 1997, 16:5639-5653.

72. Pereira R, Raingeaud J, Pironin M, Ghysdael J, Quang CT: SPI-I transforming properties depend upon specifically activated forms of the EPOR. Oncogene 2000, 19:5 I06-5IIO.

73. Mowat M, Cheng A, Kimura N, Bernstein A, Benchimol S: Rearrangements of the cellular p53 gene in erythroleukaemic cells transformed by Friend virus. Nature 1985, 3 I 4:633-636.

74. Ben-David Y, Prideaux VR, Chow V, Benchimol SaBA: Inactivation of the p53 oncogene by internal deletion or retroviral integration in erythroleukemic cell lines induced by Friend leukemia virus. Oncogene 1988, 3:179-185.

75. Munroe DG, Peacock JW, Benchimol S: Inactivation of the cellular p53 gene is a common feature of Friend virus-induced erythroleukemia: relationship of inactivation to dominant transforming alleles. Mol Cell Biol 1990, 10:3307-3313.

76. Lavigueur A, Bernstein A: p53 transgenic mice: accelerated erythroleukemia induction by Friend virus. Oncogene 1991, 6:2197-2201.

77. Prasher JM, Elenitoba-Johnson KS, Kelley LL: Loss of p53 tumor suppressor function is required for in vivo progression of Friend erythroleukemia. Oncogene 200I, 20:2946-2955.

78. Johnson P, Chung S, Benchimol S: Growth suppression of Friend virus-transformed erythroleukemia cells by $\mathrm{p} 53$ protein is accompanied by hemoglobin production and is sensitive to erythropoietin. Mol Cell Biol I993, I3:| 1456-| 463

79. Moreau-Gachelin F, Wendling F, Molina T, Denis N, Titeux M, Grimber G, Briand P, Vainchenker W, Tavitian A: Spi-I/PU.I transgenic mice develop multistep erythroleukemias. Mol Cell Biol 1996, 16:2453-2463.

80. Kosmider O, Denis N, Lacout C, Vainchenker W, Dubreuil $P$, Moreau-Gachelin F: Kit-activating mutations cooperate with Spi-I/PU.I overexpression to promote tumorigenic progression during erythroleukemia in mice. Cancer Cell 2005, 8:467-478.

8I. Rimmele P, Kosmider O, Mayeux P, Moreau-Gachelin F, Guillouf C: Spi-I/PU.I participates in erythroleukemogenesis by inhibit- 
ing apoptosis in cooperation with Epo signaling and by blocking erythroid differentiation. Blood 2007, 109:3007-3014.

82. McKercher SR, Torbett BE, Anderson KL, Henkel GW, Vestal DJ, Baribault H, Klemsz M, Feeney AJ, Wu GE, Paige C], Maki RA: Targeted disruption of the PU.I gene results in multiple hematopoietic abnormalities. Embo J 1996, I5:5647-5658.

83. Scott EW, Fisher RC, Olson MC, Kehrli EW, Simon MC, Singh $\mathrm{H}$ : PU.I functions in a cell-autonomous manner to control the differentiation of multipotential lymphoid-myeloid progenitors. Immunity 1997, 6:437-447.

84. DeKoter RP, Walsh JC, Singh H: PU.I regulates both cytokinedependent proliferation and differentiation of granulocytel macrophage progenitors. Embo J 1998, I 7:4456-4468.

85. Anderson MK, Weiss AH, Hernandez-Hoyos G, Dionne CJ, Rothenberg EV: Constitutive expression of PU.I in fetal hematopoietic progenitors blocks $T$ cell development at the pro-T cell stage. Immunity 2002, 16:285-296.

86. Zou GM, Chen JJ, Yoder MC, Wu W, Rowley JD: Knockdown of Pu. I by small interfering RNA in CD34+ embryoid body cells derived from mouse ES cells turns cell fate determination to pro-B cells. Proc Natl Acad Sci USA 2005, 102: | 3236-|324|.

87. Iwasaki H, Somoza C, Shigematsu H, Duprez EA, Iwasaki-Arai J, Mizuno S, Arinobu Y, Geary K, Zhang P, Dayaram T, Fenyus ML, Elf S, Chan S, Kastner P, Huettner CS, Murray R, Tenen DG, Akashi K: Distinctive and indispensable roles of PU.I in maintenance of hematopoietic stem cells and their differentiation. Blood 2005, 106:1590-1600.

88. Dakic A, Metcalf $D$, Di Rago L, Mifsud S, Wu L, Nutt SL: PU.I regulates the commitment of adult hematopoietic progenitors and restricts granulopoiesis. J Exp Med 2005, 201:1487-I502.

89. Klemsz MJ, McKercher SR, Celada A, Van Beveren C, Maki RA: The macrophage and B cell-specific transcription factor PU.I is related to the ets oncogene. Cell 1990, $61: 1 \mid$ 3-124.

90. DeKoter RP, Singh H: Regulation of B lymphocyte and macrophage development by graded expression of PU.I. Science 2000, 288: |439-|44|.

91. Back J, Dierich A, Bronn C, Kastner P, Chan S: PU.I determines the self-renewal capacity of erythroid progenitor cells. Blood 2004, 103:3615-3623.

92. Nutt SL, Metcalf D, D'Amico A, Polli M, Wu L: Dynamic regulation of PU.I expression in multipotent hematopoietic progenitors. J Exp Med 2005, 20 I:22I-23I.

93. Tsai SF, Martin DI, Zon LI, D'Andrea AD, Wong GG, Orkin SH: Cloning of cDNA for the major DNA-binding protein of the erythroid lineage through expression in mammalian cells. Nature 1989, 339:446-45I.

94. Evans T, Felsenfeld G: The erythroid-specific transcription factor Eryfl: a new finger protein. Cell 1989, 58:877-885.

95. Ferreira R, Ohneda K, Yamamoto M, Philipsen S: GATAI function, a paradigm for transcription factors in hematopoiesis. Mol Cell Biol 2005, 25: I 2 I 5- I 227.

96. Pevny L, Simon MC, Robertson E, Klein WH, Tsai SF, D'Agati V, Orkin SH, Costantini F: Erythroid differentiation in chimaeric mice blocked by a targeted mutation in the gene for transcription factor GATA-I. Nature 1991, 349:257-260.

97. Weiss MJ, Orkin SH: Transcription factor GATA-I permits survival and maturation of erythroid precursors by preventing apoptosis. Proc Natl Acad Sci USA 1995, 92:9623-9627.

98. Rekhtman N, Radparvar F, Evans T, Skoultchi Al: Direct interaction of hematopoietic transcription factors PU.I and GATA-I: functional antagonism in erythroid cells. Genes Dev 1999, |3:|398-|4||.

99. Zhang P, Behre G, Pan J, Iwama A, Wara-Aswapati N, Radomska HS, Auron PE, Tenen DG, Sun Z: Negative cross-talk between hematopoietic regulators: GATA proteins repress PU.I. Proc Natl Acad Sci USA 1999, 96:8705-87I0.

100. Nerlov C, Querfurth E, Kulessa H, Graf T: GATA-I interacts with the myeloid PU.I transcription factor and represses PU.Idependent transcription. Blood 2000, 95:2543-255।.

10I. Stopka T, Amanatullah DF, Papetti M, Skoultchi Al: PU.I inhibits the erythroid program by binding to GATA-I on DNA and creating a repressive chromatin structure. Embo J 2005, 24:37I $2-3723$

102. Choe KS, Radparvar F, Matushansky I, Rekhtman N, Han X, Skoultchi Al: Reversal of tumorigenicity and the block to differentia- tion in erythroleukemia cells by GATA-I. Cancer Res 2003 , 63:6363-6369.

103. Starck J, Doubeikovski A, Sarrazin S, Gonnet C, Rao G, Skoultchi A, Godet J, Dusanter-Fourt I, Morle F: Spi-I/PU.I is a positive regulator of the Fli-I gene involved in inhibition of erythroid differentiation in friend erythroleukemic cell lines. Mol Cell Biol 1999, 19:121-|35.

104. Ben-David Y, Giddens EB, Letwin K, Bernstein A: Erythroleukemia induction by Friend murine leukemia virus: insertional activation of a new member of the ets gene family, Fli-I, closely linked to c-ets-I. Genes Dev 1991, 5:908-918.

105. Tsui HW, Siminovitch KA, de Souza L, Tsui FW: Motheaten and viable motheaten mice have mutations in the haematopoietic cell phosphatase gene. Nat Genet 1993, 4:124-129.

106. Wlodarski P, Zhang Q, Liu X, Kasprzycka M, Marzec M, Wasik MA PU.I activates transcription of SHP-I gene in hematopoietic cells. J Biol Chem 2007, 282:6316-6323.

107. Barnache S, Wendling F, Lacombe C, Denis N, Titeux M, Vainchenker W, Moreau-Gachelin F: Spi-I transgenic mice develop a clonal erythroleukemia which does not depend on p53 mutation. Oncogene 1998, 16:2989-2995.

108. Scolan EL, Wendling F, Barnache S, Denis N, Tulliez M, Vainchenker W, Moreau-Gachelin F: Germ-line deletion of p53 reveals a multistage tumor progression in spi-I/PU.I transgenic proerythroblasts. Oncogene 200I, 20:5484-5492.

109. Lennartsson J, Jelacic T, Linnekin D, Shivakrupa R: Normal and oncogenic forms of the receptor tyrosine kinase kit. Stem Cells 2005, 23:16-43.

II0. Munugalavadla $V$, Kapur R: Role of c-Kit and erythropoietin receptor in erythropoiesis. Crit Rev Oncol Hematol 2005, 54:63-75.

III. Rottapel R, Reedijk M, Williams DE, Lyman SD, Anderson DM, Pawson T, Bernstein A: The Steel/W transduction pathway: kit autophosphorylation and its association with a unique subset of cytoplasmic signaling proteins is induced by the Steel factor. Mol Cell Biol I991, I I:3043-305 I.

112. Reith $A D$, Ellis C, Lyman SD, Anderson DM, Williams DE, Bernstein $A$, Pawson T: Signal transduction by normal isoforms and $W$ mutant variants of the Kit receptor tyrosine kinase. Embo J 1991, 10:245I-2459.

1 13. Serve H, Yee NS, Stella G, Sepp-Lorenzino L, Tan JC, Besmer P: Differential roles of PI3-kinase and Kit tyrosine $82 \mathrm{I}$ in Kit receptor-mediated proliferation, survival and cell adhesion in mast cells. Embo J 1995, 14:473-483.

I 4. Timokhina I, Kissel H, Stella G, Besmer P: Kit signaling through P 3-kinase and Src kinase pathways: an essential role for Racl and JNK activation in mast cell proliferation. Embo J 1998 , 17:6250-6262.

II5. Wandzioch E, Edling CE, Palmer RH, Carlsson L, Hallberg B: Activation of the MAP kinase pathway by c-Kit is PI-3 kinase dependent in hematopoietic progenitor/stem cell lines. Blood 2004, 104:5I-57.

116. Longley BJ, Tyrrell L, Lu SZ, Ma YS, Langley K, Ding TG, Duffy T, Jacobs P, Tang LH, Modlin I: Somatic c-KIT activating mutation in urticaria pigmentosa and aggressive mastocytosis: establishment of clonality in a human mast cell neoplasm. Nat Genet 1996, 12:312-314.

117. Pignon JM, Giraudier S, Duquesnoy P, Jouault H, Imbert M, Vainchenker W, Vernant JP, Tulliez M: A new c-kit mutation in a case of aggressive mast cell disease. $\mathrm{Br} J$ Haematol 1997, 96:374-376.

118. Gari M, Goodeve A, Wilson G, Winship P, Langabeer S, Linch D, Vandenberghe E, Peake I, Reilly J: c-kit proto-oncogene exon 8 inframe deletion plus insertion mutations in acute myeloid leukaemia. Br J Haematol 1999, 105:894-900.

119. Beghini A, Peterlongo P, Ripamonti CB, Larizza L, Cairoli R, Morra E, Mecucci $C$ : $C$-kit mutations in core binding factor leukemias. Blood 2000, 95:726-727.

120. Wang YY, Zhou GB, Yin T, Chen B, Shi JY, Liang WX, Jin XL, You JH, Yang G, Shen ZX, Chen J, Xiong SM, Chen GQ, Xu F, Liu YW, Chen Z, Chen SJ: AMLI-ETO and C-KIT mutation/overexpression in $\mathbf{t}(8 ; 2 I)$ leukemia: Implication in stepwise leukemogenesis and response to Gleevec. Proc Natl Acad Sci U S A 2005, 102(4): I 104-1109.

121. Barnache S, Mayeux P, Payrastre B, Moreau-Gachelin F: Alterations of the phosphoinositide 3-kinase and mitogen-activated pro- 
tein kinase signaling pathways in the erythropoietin-independent Spi-I/PU.I transgenic proerythroblasts. Blood 200I, 98:2372-238I.

122. Gilliland DG, Griffin JD: The roles of FLT3 in hematopoiesis and leukemia. Blood 2002, 100:1532-1542.

123. Speck NA, Gilliland DG: Core-binding factors in haematopoiesis and leukaemia. Nat Rev Cancer 2002, 2:502-5I3.

124. Tenen DG: Disruption of differentiation in human cancer: AML shows the way. Nat Rev Cancer 2003, 3:89-101.

125. Reilly JT: Receptor tyrosine kinases in normal and malignant haematopoiesis. Blood Rev 2003, I7:24I-248.

126. Reilly JT: Pathogenesis of acute myeloid leukaemia and inv(16)(p I 3; 22): a paradigm for understanding leukaemogenesis? Br J Haematol 2005, I 28: 18-34.

127. Rosenbauer F, Koschmieder S, SteidI U, Tenen DG: Effect of transcription-factor concentrations on leukemic stem cells. Blood 2005, 106:1519-1524.

128. Scolnik MP, Palacios MF, Acevedo SH, Castuma MV, Larripa IB, Palumbo A, Moiraghi EB, Sasot AM, Huberman AB: Promyelocytic blast crisis of chronic myelogenous leukaemia with translocations (9;22) and (15;17). Leuk Lymphoma 1998, 31:23I-236.

129. Melnick A, Licht JD: Deconstructing a disease: RARalpha, its fusion partners, and their roles in the pathogenesis of acute promyelocytic leukemia. Blood 1999, 93:3167-32I5.

130. Yamamoto Y, Kiyoi H, Nakano Y, Suzuki R, Kodera Y, Miyawaki S, Asou N, Kuriyama K, Yagasaki F, Shimazaki C, Akiyama H, Saito K, Nishimura M, Motoji T, Shinagawa K, Takeshita A, Saito H, Ueda R, Ohno R, Naoe T: Activating mutation of D835 within the activation loop of FLT3 in human hematologic malignancies. Blood 200I, 97:2434-2439.

13I. Kottaridis PD, Gale RE, Frew ME, Harrison G, Langabeer SE, Belton AA, Walker H, Wheatley K, Bowen DT, Burnett AK, Goldstone AH, Linch DC: The presence of a FLT3 internal tandem duplication in patients with acute myeloid leukemia (AML) adds important prognostic information to cytogenetic risk group and response to the first cycle of chemotherapy: analysis of 854 patients from the United Kingdom Medical Research Council AML 10 and 12 trials. Blood 200I, 98: 1752-1759.

132. Gilliland DG: Hematologic malignancies. Curr Opin Hematol 200I, 8:|89-|19I.

\section{Publish with Bio Med Central and every scientist can read your work free of charge}

"BioMed Central will be the most significant development for disseminating the results of biomedical research in our lifetime. "

Sir Paul Nurse, Cancer Research UK

Your research papers will be:

- available free of charge to the entire biomedical community

- peer reviewed and published immediately upon acceptance

- cited in PubMed and archived on PubMed Central

- yours - you keep the copyright

Submit your manuscript here:

http://www.biomedcentral.com/info/publishing_adv.asp
BioMedcentral 